\title{
Review
}

\section{Spinoza for our time: Politics and modernity}

Antonio Negri, translated by William McCuaig, with a foreward by Rocco Gangle, Columbia University Press, New York, 2013, 125pp., ISBN: 978-0231160469

Contemporary Political Theory (2017) 16, 161-164. doi:10.1057/cpt.2015.64; advance online publication 12 January 2016

While in prison, under the dubious accusation of being involved in terrorist activities, Negri did not waste his time or wallow in self-pity. He wrote The Savage Anomaly: The Power of Spinoza's Metaphysics and Politics. This book, even though it was from Italy, could be said to be part of a veritable renaissance in Spinoza studies in France in the 1960s, as usefully explained in the introduction to this book, with works by such thinkers as Matheron, Althusser, Balibar, Macherey and Deleuze. Such a renewal interest in Spinoza was quite different from the mainstream of Spinoza studies in England and America, associated with such names as Bennett, Hampshire and Curley, or even more contemporary writers like Nadler and Rocca, who rarely ever quote or refer to this other tradition of interpreting Spinoza. Not only does Negri write of Spinoza as anomaly within philosophy, but his Spinoza is also one. The difference between these writers and the dominant interpretation is that they have a strong ontological reading of Spinoza, which they immediately tie into a discourse of political emancipation. This is in contrast to a more 'contractual' reading of Spinoza that inserts him within the 'normal' sequence of Hobbes, Locke and Rousseau. For this reason, Negri's reading cannot be separated, and he has never concealed it, from his own political commitment to absolute democracy. Negri not only comes to Spinoza through Marx, but also through a long political struggle under the banner of Autonomia Operaia. It was not by chance, then, that Negri wrote his first book on Spinoza in prison.

This book is a translation of Spinoza et Nous. Of course, in terms of selling books as commodities, the publisher has to say that it contains something new, but it does not really. Where it is useful, is that in the first essay at least, 'Spinoza: A Heresy of Immanence and of Democracy', it offers a good summary of Negri's interpretation of Spinoza, and from there, if readers are convinced, or at least interested, they might go back to his more substantial work. I am less persuaded by the other essays in this small collection. Either because Negri's reading is so peculiar (I have never found him very convincing on Heidegger, in comparison, for example, with his contemporary Paolo Virno), or very slight (some of these essays are conference papers,

(c) 2016 Macmillan Publishers Ltd. 1470-8914 Contemporary Political Theory Vol. 16, 1, 161-164 www.palgrave.com/journals 
which I do not believe always deserve or require publication, unless they have been substantially rewritten).

At the heart of Negri's reading of Spinoza is a strong interpretation of his ontology. Fundamental to Spinoza's metaphysics is the relation between substance, attributes and modes. Each singular being is an expression of a common totality. Equally one can turn this expression around: the common totality is nothing but the expression of each singularity. The multiple and the one are not opposed to one another, as though the one were separate from the multiple, but the one is nothing but the individual expression of the multiple. At the heart of Spinoza's metaphysics, therefore, and Negri stresses this again and again, is a rejection of any transcendence. There is nothing outside the multiple. God, for Spinoza, is not a being that stands outside of creation, but is creation, Deus sive natura. The originality of Negri's interpretation is to make us see that this ontology has direct political consequences. As he already insisted in The Savage Anomaly, Spinoza's interruption of the Ethics to write the Political Treatise is not merely a response to the external events of the political upheaval in the United Provinces (modern-day Netherlands) in the seventeenth century (Spinoza was an admirer of the Liberal Republicans under Johan de Witt), but follows directly from his own metaphysics. The rejection of transcendence at the ontological level parallels its refusal at the political level. If Spinoza argues for absolute democracy in the Political Treatise, Democratia omnio absoluta, then this is a reflection of his own ontology. Democracy is the mirror image of an immanent ontology.

This absolute democracy, however, is not the same as a representative democracy, which emerges out of the social contract tradition. Here the power of the multitude (which is the political form of the ontological multiple) is to be feared and not admired. The aim of any representative democracy is to negate the many, and not to empower them, through passive affects (the politics of fear and false hopes). In our own time, our democracies have been neutered by the spectacle of consumption and false freedoms, where the ontological dimension is occluded. Democracy has become synonymous with representation (and this is a truism of our age, no one can imagine democracy otherwise). This is why, for Negri, Spinoza is still important to us, not as an historical curiosity argued about in political theory and philosophy departments in our universities, but as directly applicable to our age and our problems, where there is a widespread feeling, which is manifested in the falling voting share in most advanced Western democracies, that our democracy is not really ours at all, but has been co-opted by a political elite in hock to multinational corporations.

What is of particular importance to note in Spinoza's ontology is that it is an ontology not of representation but of power. Being is power. Being is not a being which represents power but the degree of power of every individual being, which Spinoza calls conatus. Each individual being, in its own way, is the expression of the infinite power of being as such. This is, Negri writes, Spinoza's materialism. It is not the reductive materialism of a crude scientism, or the absurd mythical teleology of so 
called dialectical materialism, which is a travesty of Marx's thought, but an immanent ontology of power.

The multitude, which is the subject of the third essay of this collection, 'Multitude and Singularity in the Development of Spinoza's Political Thought', is nothing but the power of the individuals that make it up. It is common. The function of representative democracy is to divide the multitudes against itself by introducing new forms of transcendence and division. This is the difference between potestas and potentia in Spinoza. Potestas is the power of authority, whereas potentia is actual force and strength of the multitude. In the society of the spectacle the real ontological relation is inverted, as though all power came from potestas and not potentia. Although on the surface, Spinoza's political thought appears to be individualist, since each individual being seeks to preserve its own being, my being only increases its power through co-operation and community with others. It is not a community of the fusion of individuals, but a co-action. Spinoza's political ontology moves from conatus, to cupiditas, and finally to amor. It is the opposite of a 'possessive idealism', which only sees in life the competitive struggle of all against all. Co-operation and productivity of individuals are what acts against exploitation. The common is not the transcendental unification of supposedly common interests, but the production of the common through individualities. It is the 'coming together' or 'being-with', where the individual is preserved rather than sublated in a higher unity.

If Negri is right that Spinoza's politics is an ontology through and through, then it should not surprise us that his interpretation would eventually come into collision with Heidegger. Already with this notion of the multitude as 'being-with', we hear echoes of Mitsein in Being and Time. Being with others is not something added onto my subjectivity but is fundamental to what it means to be me at all. The difference between them is Heidegger's ontology is one of death, whereas Spinoza's is one of life. 'Potency and Ontology: Heidegger or Spinoza', however, is a very slight essay in this collection (it was delivered as a paper in 2006 at conference on Spinoza in Berlin), so it can be difficult, through the polemic and name-calling, to discern what Negri's substantial critique of Heidegger's ontology is. Here we would have to read his book Time for Revolution (which in reality is two books written at very different times). Negri accuses Heidegger of mysticism and an ontology of nothingness and death. Against this, we are to imagine Spinoza as the representative of rationality, fullness and life. Yet even Negri must admit, and does, that there is something much more interesting going on under this sloganeering. For he knows that Heidegger rediscovers the rich ontological reality of time against its reduction to quantity and space, and in this sense, as Negri outlines in the first part of Time and Revolution, his and Marx's project are, in some ways, the same. Negri seems to want his cake and eat it. He wants to appear above the fray of political bickering (Heidegger is a Nazi and so on, and we do not need to read him), while at the same time only begrudgingly accepting that Heidegger has anything at all in common with his own project, which means that he does not analyse in depth Heidegger's own work (this is compounded

(C) 2016 Macmillan Publishers Ltd. 1470-8914 Contemporary Political Theory Vol. 16, 1, 161-164 163 
perhaps by the form of this writing, as a conference paper, and so, at least in this form, cannot provide it).

As a disparate collection of occasional writing, this small book has it strengths and weaknesses, as you might expect. The two chapters, 'Spinoza: A heresy of immanence and of democracy' and 'Multitude and Singularity in the Development of Spinoza's Thought' are good introductions to Negri's Spinoza. The other two chapters, the one on Heidegger, and the other, 'Spinoza: A Sociology of the Affects', are testimony to the fact that you should not always publish every paper you deliver at a conference (have those days gone when you would write just to speak and not to publish?). The latter, for example, is very slight indeed, and is largely made of long quotations from the Ethics. God knows what the audience made of it who had to listen to it, and I am not sure the reader will either.

\author{
William Large \\ University of Gloucestershire, Cheltenham GL50 2RH, UK \\ wlarge@glos.ac.uk
}

